\title{
FENOMENA TRADISI ZIARAH PADA KUBURAN PETTA BETTA'E PADA MASYARAKAT KABUPATEN BONE
}

\author{
Taufik \\ Samiang Katu \\ Indo Santalia \\ La Ode Ismail Ahmad \\ Program Magister Pascasarjana UIN Alauddin Makassar 2018 \\ Email: Taufikmag@gmail.com
}

\begin{abstract}
Abstrak: Ziarah pada kuburan Petta Betta'E merupakan kuburan yang keberadaannya menjadi kepercayaan yang telah turun temurun diyakini sebagai tempat keramat, karena yang bersemayam merupakan arwah leluhur yang dianggap memiliki peranan penting dalam kehidupan masyarakat. Dalam melihat persepsi masyarakat Palakka terhadap tradisi ziarah kuburan Petta Betta'E secara garis besar mejadi sebuah wadah dalam mengespresikan kepercaan mereka, adanya aggapan dengan menziarahi dapat memberikan kemanfaatan bagi kehidupan. Adanya kepercayaan demikian telah mengotori konsep ziarah itu sendiri sebagai wadah seseorang untuk mengingat akan kematian, karena sesungguhya sesorang yang telah meninggal, tidaklah mampu memberikan kemanfaatan. Dalam upaya tokoh Agama setempat dalam meluruskan kepercayaan masyarakat Palakka, dengan memberikan nasihat-nasihat keagamaan dengan berlahan tanpa menyakiti perasaan masyarakat dan menjalin hubungan interaktif dengan masyarakat sehingga dapat terjalin kekeluargaan, seta memberikan wujud pembinaan kepada masyarakat dengan pembinaan harian dan pembinaan mingguan. Dari pembinaan harian berusaha memupuk masyarakat dengan bekal ilmu agama, sedangkan pembinaan mingguan dilakukan sebagai wujud penanaman pemahaman masyarakat dalam menyikapi persoalan keagamaan. sehingga dengan kedua proses tersebut secara berlahan dapat mengubah kepercayaan masyarakat sedikit demi sedikit.
\end{abstract}

\section{Keywords: $\quad$ Petta Betta'E, Ziarah Kuburan}

\section{PENDAHULUAN}

Dalam Islam, ilmu merupakan salah satu perantara untuk memperkuat keimanan. Iman hanya akan bertambah dan menguat, jika disertai ilmu pengetahuan. Seorang ilmuan besar, Albert Enstein mengatakan sebagaimana yang dikutip oleh Russel Stannard, "Science without religion is blind, and religion without science is 
lame” (Ilmu tanpa agama buta, dan agama tanpa ilmu adalah lumpuh). ${ }^{1}$ Seperti halnya ziarah kubur, perlu adanya pemahaman untuk seseorang dalam melakukannya, sehingga mereka akan paham tentang fungsi ziarah yang sebenarnya. Dalam kalangan masyarakat di indonesia, ziarah bukanlah suatu yang hanya sering diucapkan, namun telah menjadi kebiasaan yang rutin dilakukan.

Ziarah kubur terdiri dari dua kata, yakni ziarah dan kubur, ziarah artinya menengok, mengunjungi atau mendatangi. Sedangkan yang disebut dengan kubur, adalah tempat dimana orang yang telah meninggal di semayamkan di dalamnya. Maka ziarah kubur merupakan kegiatan menengok atau mengunjungi tempat dimana orang yang meninggal disemayamkan. ${ }^{2}$ Dari hal tersebutlah sehingga manusia diharapkan mengambil pelajaran dan peringatan, bahwa pada akhirnya mereka juga akan meninggal, karena kuburan merupakan akhir dari perjalanan kehidupan seseorang di dunia.

Manusia dalam menjalani kehidupan ini tidak merasa terbebani, mereka akan sadar bahwa semua yang hidup akan mengalami kematian, dan harus mempertanggungjawabkan segala perbuatan semasa hidupnya, sehingga hal itu semakin mempermudah manusia untuk melakukan kebaikan dan meninggalkan keburukan. Pada esensinya, dalam ziarah kubur yang memegang peranan penting adalah adanya keyakinan bahwa hanya kepada Allah manusia meminta ampun dan memohon pertolongan, sehingga segala sesuatu yang dilakukan manusia itu berorientasi hanya beribadah kepada-Nya, bukan kepada yang lain. Sebagaimana Allah berfirman dalam QS Yunus/11:106.

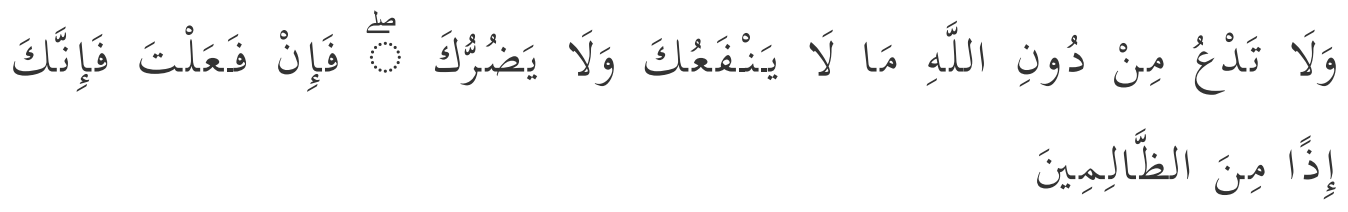

Terjemahannya:

Dan janganlah kamu menyembah apa-apa yang tidak memberi manfaat dan tidak (pula) memberi mudarat kepadamu selain Allah; sebab jika kamu berbuat (yang demikian) itu, maka sesungguhnya kamu termasuk orang orang yang dzalim. ${ }^{3}$

Islam telah mengajarkan seseorang agar tidak meminta apapun selain kepada Allah. Namun ketika ada harapan untuk mendapatkan sesuatu dengan meminta selaian kepada Allah atau kepada orang yang telah meninggal, maka perbuatan itu tidak diperkenankan oleh syariat Islam, Seperti dalam tradisi ziarah pada kuburan Petta Betta'E, peziarah datang dengang berbagai kepentingan dan latar belakang permasalahan yang berbeda, dengan sisi keduniawian, berharap segala sesuatu akan mudah dan lancar ketika telah melakukan ziarah ke kuburan tersebut.

${ }^{1}$ Russel Stannard, Tuhan Abad 21, terj. Happy Susanto (Yogyakarta: Belukar Budaya, 2004), h.

${ }^{2}$ Sibtu Asnawi, Tata Cara Ziarah Kubur (Kudus: Menara, 1983), h. 2

${ }^{3}$ Kementrian Agama RI, Al-Qur'an dan Terjemahnya (Surabaya: Halim, 2014), h. 220 
Kuburan Petta Betta'E telah menjadi objek wisata bagi masyarakat setempat dan bahkan tidak jarang masyarakat luar datang untuk berziarah. Adanya hal yang unik pada kuburan tersebut, berupa posisinya nampak berbeda dengan kuburan yang lain berupa arah kuburannya, memberikan kesan brbeda dalam melihat kuburan tersebut.

Banyaknya kuburan tua yang berada di sekitaran kuburan Petta Betta'E, namun hanya kuburan tersebut yang terlihat megah yang di berikan hiasan berupa kain-kain yang dipasang seperti lamming pada setiap ruangan, pada laintainya diberikan karpet, dan dipagari dengan pagar besi, sehingga dari tampilan kuburannya terlihat angker. Bagi masyarakat berziarah ke kuburan Petta Betta'E ini sudah menjadi hal yang turun temurun dilakukan oleh para leluhurnya (Attoriolong), sehingga paradigma masyarakat telah terisolasi, bahwa berziarah ke kuburan Petta Betta'E adalah suatu hal yang positif untuk dilakukan, demi mendapatkan kehidupan yang harmonis sehingga dijauhkan dari hal-hal yang dapat merusak kehidupan mereka, apakah itu berkaitan dengan kesehatan, karir ataupun yang lainnya yang dapat berdampak negatif bagi kelangsungan hidup mereka sehari-hari. Karena masih berkaitan dengan kepercayaan masyarakat Bugis yang meyakini adanya kekuatan gaib atau kekuatan supranatural dari seorang tokoh yang terkemuka yang dianggap keramat, sekalipun telah meninggal.

Secara teologis keyakinan keimanan para peziarah masih ambivalen, campur aduk, dan tidak murni. Satu sisi menyatakan ketauhidannya secara mutlak akan tetapi di sisi lain menyimpan kepercayaan-kepercayaan tertentu terhadap kuburan-kuburan yang dianggap keramat tersebut. Persoalannya kemudian adalah apabila ziarah ke kuburan yang diyakini masyarakat luas sebagai tempat keramat, maka niat bisa jadi tetap berada pada garis yang lurus, atau mungkin juga telah terjadi penyimpangan sehingga dapat membahayakan kemurnian aqidah para peziarah karena dalam ritualnya terjadi tumpang tindih antara hal-hal yang berasal dari agama dan tradisi atau bahkan telah jatuh dalam praktek kemusyrikan.

Melihat dengan adanya tradisi yang dilakukan pada kuburan Petta Betta'E sebagai tempat yang keramat, maka perlu adanya penelitian yang dilakukan sebagai usaha mengetahui tindakan dan pemahaman masyarakat pada tradisi ziarah tersebut, sehingga ada upaya-upaya yang bisa dilakukan untuk mencegah agar tidak terjadi kesalah pahaman pada masyarakat dalam mepercayai tradisi ziarah tersebut.

Sehubungan dengan hal diatas, maka pokok permasalahan dalam penelitian adalah bagaimana fenomena tradisi ziarah pada kuburan Petta Betta'E dalam pandangan aqidah Islam?

\section{TRADISI ZIARAH KUBUR}

\section{Pengertian Tradisi}

Kata Tradisi berasal dari bahasa latin "tardere" yang mengandung beberapa pengertian antara lain: mengantarkan, mewariskan dan menyalurkan. ${ }^{4}$ Merujuk pada kata dasar tersebut, maka tradisi dapat dimaknai adanya sebuah proses yang berulang tentang sesuatu yang disampaikan atau diwariskan dan seterusnya dari generasi ke

${ }^{4}$ Mircea Eliade et. Al, The Encyclopedia of Religion (New York: Macmillian Publishing Company, 1987), th. 
generasi atau dari masa lalu dan masih berlaku hingga masa sekarang, masa dimana manusia mengalami perkembangan dan perubahan pesat. Dengan demekian karakter dasar yang dimiliki "tradisi" adalah sifatnya yang bertahan karena senang tiasa dijaga dan dilestarikan dari waktu ke waktu.

Tradisi ziarah kubur pada dasarnya telah menjadi suatu agenda terdiri dalam rutinitas keagamaan. Dalam Islam, ziarah kubur dianggap sebagai perbuatan yang hukumnya mubah, yang merupakan suatu kebolehan untuk dilakukan.

Ziarah ke kubur merupakan suatu hal yang sudah ada sejak awal kedatangan Islam. Dilihat dari segi perkembangannya, ada catatan menarik yang patut kita perlihtakan. Konon, Nabi Muhammad saw pernah melarang ummatnya pada waktu itu masih dini dan belum kuat dalam segi akidahnya untuk berhadapan dengan hal-hal yang bisa menyeret mereka kedalam perbuatan syirik. Jadi munculnya larangan dikarenakan adanya suatu perilaku kepada tanda kesyirikan, dan diperbolehkan jika kegiatan ziarah kubur itu jauh dari nilai syirik.

\section{Fenomena Ziarah Kubur}

Dalam fakta sejarah, paganisme merupakan agama sesat pertama yang dianut oleh manusia, bermula ketika mereka membutuhkan panutan untuk dijadikan sebagai pedoman hidup, mereka mengangkat pemimpin yang shaleh, dicintai dan dihormati. Penghormatan tersebut tidak terbatas pada saat sang pemimpin masih hidup, namun berlanjut ketika dia sudah meninggal. Hal tersebut diwujudkan dengan membuat patungnya sebagai simbol penghormatan yang pada akhirnya digunakan sebagai sesembahan.

Buhairi menyebutnya fenomena menyembah patung ini sudah mulai bergeser bentuk pada zaman sekarang. Pergeseran bentuk itu mengarah pada pengkultusan, pengeramatan atau pengagungan kubur tertentu dan meminta segala kebutuhan kepadanya. ${ }^{5}$ Bahkan seorang kuburi ${ }^{6}$, berkeyakinan bahwa mengunjungi kubur wali sama dengan mendapatkan kenikmatan dunia dan akhirat. ${ }^{7}$ Sebagian dari mereka juga menyamakan kubur wali dengan Baitullah al-Haram (ka'bah) dan menziarahinya dianggap sebagai pelaksanaan ibadah haji dan sebagainya. Disinyalir bahwa telah terjadi kesalah pahaman persepsi tentang ziarah kubur sehingga berbagai penyimpangan yang dilakukan oleh para peziarah kubur.

Farhan mengungkapkan bahwa saat ini kaum muslimin telah melakukan berbagai macam bentuk kemusyrikan di kuburan, seperti mengusap-usap kuburan, mencari berkah di kuburan, bertawashul dengan orang-orang yang telah meninggal karena kesalehannya dan beristighotsah (meminta pertolongan) kepada mereka. ${ }^{8}$ Sebagaimana Esposito melihat faham wahabi sangat membenci kegiatan ziarah kubur. Menurutnya, pada tahun 1925, pengikut wahabiyah meratakan seluruh bangunan kuburan ini.

${ }^{5}$ Syaikh Mamduh Farhan al-Buhairi, Kuburan Agung, Menyingkap Fenomena Ketergantungan Kepada Para Wali, terj. A. Hasan Bashori (Jakarta: Darul Haq, 2005), h. 14

${ }^{6}$ Sebutan bagi penyembah kuburan.

${ }^{7}$ Syaikh Mamduh Farhan al-Buhairi, Kuburan Agung, Menyingkap Fenomena Ketergantungan Kepada Para Wali, h. 55

${ }^{8}$ Syaikh Mamduh Farhan al-Buhairi, Kuburan Agung, Menyingkap Fenomena Ketergantungan Kepada Para Wali, h. 11 
Sebelumnya, pada tahun 1801, Wahabiyah menyerbu dan menghancurkan kuburan yang ada di Karbala dan Najaf. Kepercayaan Wahabiyah tanpa ada sumbang pemikiran lain dari komunitas Sunni dalam soal ini memandang ziarah secara umum sebagai "pemujaan terhadap orang suci", yang mengarah pada dosa syirik, yakni menyekutukan Tuhan dengan orang-orang suci ini. ${ }^{9}$

Hal serupa telah dikemukakan oleh Humaidi yang menyatakan bahwa ziarah kubur sudah menjadi budaya yang telah diplesetkan dan mungkin sangat sulit untuk diluruskan. Nilai ibadah yang semula ada pada ritual itu disulap menjadi suatu yang bid'ah, mereka membuat hari-hari tertentu yang seakan wajib untuk berziarah kubur, menentukan kubur orang tertentu untuk diziarahi bahkan ada yang menjadikan ziarah kubur sebagai komoditi bisnis. ${ }^{10}$

Setidaknya ada delapan penyebab munculnya berbagai penyimpangan di kuburan yang dikemukakan oleh Farhan, yaitu: Kebodohan terhadap hukum-hukum agama, berbaurnya budaya-budaya, terpecahnya negara Islam, aneka ragam peradaban, fanatisme yang berlebihan terhadap tokoh, mengutamakan akal diatas wahyu, tasyabbuh (menyerupai) pada orang-orang kafir dan terjemahan buku-buku filsafat. ${ }^{11}$

Sementara Abdullah mengungkapkan bahwa salah satu pendorong orang melakukan kemusyrikan di kuburan adalah karena mereka (para peziarah) mengikuti para ulama su' ${ }^{12}$ dan hanya taklid kepada nenek moyang. ${ }^{13}$

Menurut Koenjraningrat, kebudayaan mengandung tujuh unsur pokok yang sifatnya universal yaitu : bahasa, sistem pengetahuan, sistem religi, sistem peralatan hidup dan teknologi, sistem mata pencaharian, sistem sosial, dan kesenian. ${ }^{14}$ Kebudayaan cenderung diikuti masyarakat pendukungnya secara turun-temurun dari generasi ke generasi berikutnya, meskipun sering terjadi anggota masyarakat datang sili berganti disebabkan munculnya bermacam-macam faktor kematian dan kelahiran.

Dalam suatu realita kebudayaan akan selalu dalam proses perubahan sebab itu, corak kebudayaan akan terus mengalami perbedaan dari zaman ke zaman seiring dengan kemajuan teknologi dan ilmu pengetahuan. Satu hal yang membuat perubahan

9John L. Esposito, Ensiklopedi Oxford Dunia Islam Modern (Bandung: Mizan, 2001), h. 169

${ }^{10}$ Hamid Al-Humaidi Abdullah, Bid'ah-Bid'ah Kubur, terj. Abdul Rosyad Shiddiq (Jakarta: Pustaka Al-Kautsar, 2003), x

${ }^{11}$ Syaikh Mamduh Farhan al-Buhairi, Kuburan Agung, Menyingkap Fenomena Ketergantungan Kepada Para Wali, h. 25

${ }^{12}$ Ulama $s u$ ' artinya ulama yang dengan ilmu yang dimilikinya digunakan sebgai tujuan untuk mendapatkan kenikmatan dunia, meraih gengsi, dan kedudukan.

${ }^{13}$ Hamid Al-Humaidi Abdullah, Bid'ah-Bid'ah Kubur, h. 50

${ }^{14}$ Koentjaraningrat, Pengantar Ilmu Antropologi (Jakarta: Aksara Baru, 1980) h. 217 
itu adalah gerak kebudayaannya, ada yang cepat da nada juga yang lambat dalam merespon kebudayaan lain.

Menghormati leluhur atau nenek moyang dapat diungkapkan melalui tradisi ziarah kubur. Ziarah kubur dilakukan untuk menghormati arwah nenek moyang, kedua orang tua dan keluarga yang dikuburkan, disamping itu untuk mengingatkan berziarah tentang akhirat. Kata ziarah kubur diartikan dengan berkunjung dengan ke tempat yang dianggap keramat atau yang mulia, kubur dan sebagainya sedangkan kata kubur adalah tempat dimana orang di kuburkan.

Ziarah kubur juga dapat dikatakan sebagai mengunjumgi suatu tempat yang dimuliakan atau dianggap suci, misalnya mengunjungi kubur Nabi Muhammad saw di Madinah seperti yang sering dilakukan oleh jamaah haji. Kubur yang menjadi perhatian para peziarah khususnya bagi kaum muslim biasanya kubur orang-orang yang semasa hidupnya membawah misi kebaikan terhadap lingkungannya yaitu:

a. Para Nabi dan Pemimpin Agama, mereka yang telah menyebarkan Agama serta mengajarkan mereka terhadap hal-hal kebaikan yang sesuai dengan syariat

b. Para wali, ulama dan ilmuan besar yang memberikan ilmu pengetahuan serta mengenalkan manusia terhadap Kitab Tuhan serta ilmu alam dan ilmu ciptaan

c. Kelompok orang-orang tertentu seperti kerabat, sahabat, saudara terdekat mereka yang mempunyai tali kasih atau pengorbanan semasa hidupnya.

Ziarah kubur yang telah memberikan tambahan ekonomi kepada penduduk sekitar dilokasi tersebut, sehingga masyarakat banyak yang berjualan keperluan para peziarah. Bagi tokoh-tokoh agama tertentu, terutama bagi kalangan tradisional upacara tradisi lokal ini bermanfaat untuk alat mobilisasi masyarakat kelas bawah, alat politik bagi tokoh-tokohnya, dan menjadikan sumber ekonomi yang mencukupi bagi sang tokoh keagamaan bisa dijadikan untuk memperkuat kharismnya. Ziarah kubur merupakan satu dari sekian tradisi yang ada dan berkembang di masyarakat, berbagai maksud dan tujuan serta motivasi selalu menyertai aktivitas ziarah kubur. Ziarah kubur yang dilakukan oleh masyarakat ke kubur dianggap keramat karena sebenarnya ziarah kubur adalah tradisi agama Hindu yang pada masa lampau memuja terhadap roh leluhur.

Menurut sztompka, sebagaimana yang dikutip oleh Thohir, ${ }^{15}$ tradisi lahir melalui tradisi lahir melalui dua cara. Pertama bersifat kultural, artinya ia muncul dari bawah, spontan dan massif. Perhatian, kecintaan dan kekaguman yang disebarkan melalui berbagai cara kemudian mempengaruhi rakyat. Sikap takzim dan kagum itu berubah menjadi perilaku dalam bentuk upacara, pemugaran peninggalan dan penafsiran ulang atas keyakinan, kekaguman dan tindakan individual menjadi milik bersama dan berubah menjadi fakta sosial sesungguhnya. Kedua, bersifat struktural. Ia terbentuk dari kekuasaan elit dan melalui mekanisme paksaan. Sesuatu yang sesungguhnya bersifat personal dianggap sebagai tradisi pilihan dan dijadikan tradisi kolektif melalui jalur kekuasaan seorang Raja. Raja mungkin memaksakan tradisi dinastinya pada rakyat atau

${ }^{15}$ Piotr Sztompka, Sosiologi Perubahan Sosial (Jakaarta: Prenada media Group, 2012), h. 26. 
kebiasaan-kebiasaan raja yang lantas dipaksakan menjadi tradisi rakyat, bahkan menjadi kebudayaan bersama.

Tradisi atau adat-istiadat atau disebut juga adat tata kelakuan, menurut Koentjaraningrat, tradisi atau adat istiadat dapat dibagi dalam empat tingkatan, yaitu:

Pertama, tingkat nilai budaya, kedua, tingkat norma-norma, ketiga, tingkat hukum, dan keempat, tingkat aturan khusus, tingkat nilai budaya berupa ide-ide yang mengonsepsikan hal-hal yang paling bernilai dalam kehidupan masyarakat, biasanya berakar dalam bagian emosional dan alam jiwa manusia. ${ }^{16}$

Tingkat norma-norma yaitu berupa nilai-nilai budaya yang sudah terkait kepada peranan masing-masing anggota masyarakat dalam lingkungannya.dan tingkat adat adalah system hukum yang berlaku. Terakhir adalah tingkat ukuran khusus yang mengatur kegiatan-kegiatan yang jelas terbatas ruang lingkupnya dalam masyarakat dan bersifat konkret. Dapat diambil kesimpulan bahwa tradisi adalah tata kelakuan berdasarkan ide-ide sesuai norma-norma yang berlaku pada aturan setempat dan bersifat konkret.

Kunjungan ke kubur pada dasarnya merupakan tradisi yang menyerupai ajaran Hindu yang pada masa lampau berupa pemujaan terhadap roh leluhur. Ziarah kubur merupakan satu dari sekian tradisi yang hidup dan masih berlanjut sampai sekarang. Perubahan-perubahannya terlihat pada ritual-ritual ziarah kubur.

Kubur yang dianggap keramat juga termasuk pengaruh masa Jawa Hindu. Pada masa itu, kedudukan raja masih dianggap sebagai titisan dewa atau wakil Tuhan dibumi, sehingga segala sesuatu yang berhubungan dengan seorang raja masih dianggap keramat termasuk kubur, benda-benda pusaka peninggalan (arajag) dan lainnya. Keberadaan kubur tokoh tertentu, seperti para tokoh, ahli agama atau sufi menimbulkan daya tarik bagi masyarakat untuk melakukan aktivitas ziarah dengan berbagai macam motivasi.

Banyaknya anggapan bahwa dengan berziarah ke kubur leluhur atau tokohtokoh magis tertentu dapat menimbulkan pengaruh tertentu. Kisah keunggulan atau keistimewaan tokoh yang dikuburkan merupakan daya tarik bagi masyarakat untuk mewujudkan keinginan maupun hajatnya.

Suatu hal yang menarik dari tradisi ziarah kubur (pada kubur yang dikeramatkan) adalah nilai irasional atau abstrak dari tradisi tersebut yang diyakini oleh para peziarahnya. Masyarakat sekarang yang mengalami kemajuan, ilmu pengetahuan dan teknologi merupakan hal yang penting dari kehidupan manusia modern. Sikap rasional merupakan ciri khas masyarakatnya, tetapi nampaknya manusia menyadari bahwa ada ketakutan yang luar biasa diluar dirinya. Karena itulah sebagian manusia mengapresiasinya melalui ziarah kubur. Bagi yang meyakini kekuatan hebat dan luar biasa itu adalah milik Allah swt. maka tradisi ziarah kubur dianggap sebagai apresiasi

\footnotetext{
${ }^{16}$ Koentjaraningrat, Antropologi Budaya (Jakarta: PT. Rineka Cipta, 2009), h. 120
} 
memberikan penghormatan kepada ahli kubur yang memiliki karamah. Akan tetapi sebagian manusia juga menganggap bahwa ahli kubur tersebut dapat mengabulkan hajatnya karena semasa hidupnya dianggap orang yang sakti.

Seperti yang telah disinggung diatas, maka tradisi ziarah dapat diartikan sebagi adat-istiadat atau kebiasaan masyarakat untuk berkunjung ke kubur, apabila dilakukan dengan cara serta tuntunan Islam maka akan menjadi perbuatan yang baik sehingga dapat meinimbulkan kesadaran, jika tidak mala justeru akan menjadi malapetaka.

\section{Tradisi Ziarah di Indonesia}

Tradisi ziarah dalam masyarakat Islam Indonesia merupakan sebuah tradisi lama yang terus berlangsung dan dilestarikan dalam setiap lintas generasi dan bertahan sampai sekarang.

Ziarah ke tempat yang suci atau keramat telah berlangsung sebelum Islam masuk ke Indonesia. Salah satu tradisi berziarah yang berlangsung sebelum Islam datang ke Indonesia adalah "tradisi pandusa dan candi". Pandusa berasal dari zaman pra sejarah, pada masa Islam, bangunan itu menjadi kijing atau kujingan atau jirat. Di samping jirat terdapat nisan yang pada masa pra sejarah berupa menhir. ${ }^{17}$ Pada zaman pra sejarah, pandusa yang di bawahnya diletakkan mayat, adalah tempat meletakkan bunga. Dengan adanya penempatan bunga berarti ada tradisi pada zaman pra-sejarah di mana di bawah pandusa itu terdapat mayat kubur. ${ }^{18}$

Pada zaman purba, bangunan itu berubah menjadi candi. Tokoh masyarakat yang dulunya sebagai "datu" itu menjadi "raja" setelah meninggal jasadnya dibakar dan diperipih atau benda yang disukainya dimasukkan ke dalam candi. Inilah yang disebut dicandikan. Barang yang dimasukkan dalam candi tersebut disebut diperipih sebagai simbol bahwa raja yang dicandikan, maka diatas candi dibuat arca perwujudannya, atau simbol lain seperti Lingga dan Yoni. Biasanya acara perwujudannya itu disesuaikan dengan kehidupannya di dunia, mungkin menjadi Syiwa, Wisnu, Atau Budha. Jika yang meninggal itu permaisuri, maka perwujudannya pun sesuai dengan kehidupannya di dunia. Mungkin menjadi "prajanaparamita".

Ziarah juga berhubungan dengan animisme dan dinamisme. Selanjutnya pada masa Hindu unsur itu masih ada, namun mengalami perkembangan. Khususnya untuk pendidikan agama Hindu atau Budha. Ketika Islam datang ke Indonesia, tradisi ziarah masih tetap ada. Bahkan berkembang subur. Hal ini disebabkan karena di samping sudah menjadi tradisi atau budaya yang berkembang di Indonesia pra Islam, Islam sendiri memperbolehkan dan mengajarkan tentang ziarah kubur. Dalam masyarakat

${ }^{17}$ Mahmudi, Motivasi Ziarah Makam Bagi Masyarakat Islam Studi Kasus Para Peziarah Makam Batu Ampar, Tesis (Surabaya: Pasca Sarjana Iain Sunan Ampel, 2004), h. 33

${ }^{18}$ Mashudi, Ziarah Kemakam Islam Sunan Ampel Surabaya (Surabaya: Jurnal Sastra Dan Sejarah, No. 2/II/1999), h. 39. 
Islam Jawa dikenal dengan istilah nyekar, nyadran ${ }^{19}$ itulah praktek ziarah kubur yang dilakukan oleh umat Islam Indonesia.

\section{METODOLOGI PENELITIAN}

Penelitian ini menggunakan dua sumber data yaitu data primer dan data sekunder. Data primer terdiri dari Pengurus / Juru kunci Kuburan Petta Betta'E, mengambil sebagian Jamaah/masyarakat yang masih berziarah, dan tokoh agama, tokoh adat sekaligus tokoh masyarakat. Data yang sudah terkumpul kemudian diolah dan dianalisa secara kualitatif dengan pendekatan fenomenologis dan teologis. Pendekatan teologis digunakan ketika menganalisis fenomena masyarakat Palakka pada tradisi ziarah Petta Betta' $E^{20}$ Sedangkan pendekatan fenomenologis digunakan dalam memahami segala bentuk peristiwa dan tindakan masyarakat, berupa renspon dari apa yang di fahami dari tradisi ziarah tersebut.

\section{IV.HASIL PENELITIAN}

\section{A. Profil Petta Betta'E}

Belum ada yang penulis temukan karya ilmiah atau buku yang menerangkan tentang riwayat dan cerita riwayat hidup Petta Betta'E yang kuburannya berada di Kelurahan Watang Palakka. Namun ada sedikit informasi yang diperoleh dari beberapa keterangan para sejarawan yang mengetahui Petta Betta'E, dan itupun sangat terbatas dan belum terjamin validitasnya. Karena hanya didasari oleh mitos-mitos yang menyelimuti pemahaman masyarakat yang didapat dari cerita tutur sebaya sebagai pelengkap pengetahuan mereka.

Menurut A. Rizki Arwansyah Petta Betta'E itu merupakan Raja pertama Kerajaan Pallakka, yang bernama Lapatikkengi Arung Palakka. Lapatikkengi Arung Palakka memerintah sekitar sebelum tahun 1500-an, yang merupakan ayah dari Mangkau Bone ketiga Lasaliu Karampelua (142-1496). Menurutnya Petta Betta'E merupakan Raja yang sangat sulit untuk di taklukkan pada masanya, kerajaan Palakka merupakan kerajaan yang dulunya terpisah dari kerajaan Bone, salah satu kerajaan kecil namum beriring dengan berjalannya waktu maka kerajaan Palakka telah bergabung dan berada pada naungan kerajaan Bone. Petta Betta'E merupakan sosok yang tidak pernah takut dan akan melakukan apa saja yang dikehendakinya, sehingga Petta Betta'E merupakan salah satu sosok yang di takuti, lebih lanjut dikatakan pernah ada dulu yang

${ }^{19}$ Mahmudi, Motivasi Ziarah Makam Bagi Masyarakat Islam Studi Kasus Para Peziarah Makam Batu Ampar, Tesis, h. 34

${ }^{20}$ Robert Boghdan dan Steven J. Taylor, Pengantar Metodologi Penelitian Kualitatif, terj. ArifFurchan (Surabaya: Usaha Nasional, 1992), h. 22 
ingin mencari dan mau meneliti tentang silsilah keturunannya itu Petta Betta'E, akan tetapi tidak bisa ditemukan ${ }^{21}$

Berdasarkan julukan Petta Betta'E, ketika kita melihat dari segi bahasa dari makna Petta Betta'E, "Petta", yaitu merupakan sebuah julukan yang diberikan untuk seorang bangsawan Bugis dan "Betta", yang artinya nakal, dulunya julukan sering dikaitkan dengan karakter dan watak yang dimiliki oleh seorang tokoh, sehingga bisa diambil sebuah penjelasan, hal itu juga berlaku bagi Petta Betta'E. Namun secara makna, maksud dari julukan Petta Betta'E menurut H. Rijal yang beliau ketahui itu merupakan julukan yang diberikan atas dasar sifat dan karakternya yang pemberani, dan memiliki kekuatan untuk menjadi seorang yang disegani pada zamannya. ${ }^{22}$ Namun Apping mengatakan kalau konon kenapa diberi nama Petta Betta'E karena dulunya dia nakal dan tidak mau mendengarkan apa-apa. Maka dari pernyataan ini bisa kita pahami bahwa julukan makna Petta Betta'E lebih mengarah kepada karakter yang keras kepala dan tidak ingin mendengarkan apapun, sehingga lebih mengikuti keinginan diri sendiri. $^{23}$

Dari pernyataan di atas, putusnya pengetahuan sejarah dan ketidak fahaman masyarakat, dikarnakan tidak adanya tulisan dan referensi tentang sosok Petta Betta'E. Namun sosok Petta Betta'E melalui cerita-cerita yang berkembang dari orangtuaorangtua terdahulu.

\section{B. Fenomena Ziarah kubur Petta Betta'E Pada Masyarakat Kabupaten Bone}

\section{Keadaan Kuburan Petta Betta'E}

Kuburan Petta Betta'E merupakan kuburan yang terletak di Kelurahan Watang Palakka Kecamatan Tanete Riattang Barat Kabupaten Bone. Seperti pula kuburan keramat lainnya yang memiliki cerita tentang kekeramatan, maka begitupula dengan kuburan Petta Betta'E.

Keunikan yang ada pada kuburan Petta Betta'E, berupa kondisi kuburan yang posisinya berbeda dengan kuburan yang ada pada umumnya, berupa arah kuburan yang mengarah ke arah timur-barat, tidak seperti makan pada umumnya yang arah kuburannya berada pada utara-selatan. Namun kebanyakan masyarakat memahami fenomena tersebut sebagai suatu yang luarbiasa yang melalui proses mistis, Seperti yang dikatakan Ibu Bunga, dahulu posisi kuburan Petta Betta'E sama dengan kuburan yang ada pada umumnya, namun kuburan tersebut berbalik dengan sendirinya. ${ }^{24}$ Kepercayaan tersebut yang peneliti amati telah berkembang pada masyarakat Palakka, sehingga kuburan tersebut selalu diidentikkan dengan kemampuan yang tidak mampu dijangkau oleh akal fikiran dan telah menjadi hal yang metafisik.

${ }^{21}$ A. Rizki Arwansyah (32 tahun), Sejarawan Bone, Wawancara, Watampone, 20 November

${ }^{22}$ H. Rijal (37 tahun), Masyarakat Palakka, Wawancara, Watampone, 20 Mei 2018

${ }^{23}$ Apping (34 tahun), Sejarawan Bone, Wawancara, Watampone, 20 November 2017

${ }^{24}$ Bunga (70 tahun), Masyarakat Palakka, Wawancara, Watampone, 10 November 2017 
Berebeda pula dengan pernyataan juru kunci kuburan, menurutnya sebelum Islam masuk dan menyebar di Bone, kuburan Petta Betta'E telah ada, sehingga kenapa posisi kuburannya berbeda dengan kuburan yang lain, itu disebabkan dulunya belum ada posisi yang menentu tentang kemana arah untuk menguburkan jenazahnya. ${ }^{25}$

Mengenai luas kubura Petta Betta'E, lebarnya sekitar $5 \mathrm{~m}$, dengan panjang sekitar $6 \mathrm{~m}$, dengan menggunakan atap diatasnya, dan seluruh bagian kuburan dihiasi dengan lamming, ${ }^{26}$ dengan kain yang berwarna hijau bercampur merah, dan lantainya dipasang keramik dan diberikan karpet yang memenuhi lantai, sehingga para peziarah bisa duduk dalam melakukan ziarah.

Dapat sisimpulkan, bahwa keberadaan kuburan Petta Betta'E sudah ada sebelum islam masuk dan berkembang pada masyarakat sehingga posisi kuburan tersebut belum ditentukan seperti halnya Islam telah menyatu dan telah mengatur hal tersebut. Sehingga adanya kepercayaan bahwa kuburan Petta Betta'E berbalik dengan sendirinya, maka hal tersebut hanya merupakan cerita yang tidakmampu dibuktikan.

\section{Proses Ziarah dan Perilaku Ziarah pada Kuburan Petta Betta'E}

Dalam pelaksanaan ziarah pada kuburan Petta Betta'E tentu memiliki tahapantahapan dalam melakukan ziarah, sebagai suatu tanda pengkhidmatan pada proses tradisi yang ada.

Adapun tahapan-tahapan yang biasanya dilakukan dalam menziarahi kuburan Petta Betta'E menurut juru kunci kuburan, diantaranya:

1) Mendaftarkan nama peziarah pada petugas kuburan, dengan membayar biaya kontribusi sebesar Rp. 5000

2) Menuliskan hajat (hal yang diniatkan untuk berziarah) dan diserahkan kepada pabbaca/juru kunci kuburan

3) Menyiram dan menaburkan bunga pada kuburan

4) Pembacaan doa atau hajat oleh pabbaca/juru kunci

5) Berdoa secara perorangan

6) Jika hendak keluar dari kuburan, harus dengan cara berjalan mundur. ${ }^{27}$

Seperti halnya proses ziarah yang dilakukan di atas, yang telah disebutkan oleh juru kunci kuburan, namun ada halnya Ibu Bunga menambahkan, bahwa kebiasaan yang dilakkukan dalam menziarahi kuburan Petta Betta'E, sebelum kita pergi menziarahi, terlebih dulu dilakukan mabbaca-baca untuk diniatkan pada roh Petta Betta'E yang dianggap masih selalu ada dan menghuni kuburan tersebut. ${ }^{28}$ Mabbaca-baca merupakan

${ }^{25}$ Dg. Rakile (75 tahun), Juru Kunci Makam, Wawancara, Watampone, 27 November 2017

${ }^{26}$ Lammingadalah sebuah hiasan atau dekorasi ruangan yang berwarna-warni dengan adanya hiasan sulam, yang biasanya digunakan padab acara pernikahan suku Bugis-Makassar sebagai hiasan rumah pengantin serta pada baruga.

${ }^{27}$ Dg. Rakile (75 tahun), Juru Kunci Makam, Wawancara, Watampone, 27 November 2017

${ }^{28}$ Bunga (70 tahun), Masyarakat Palakka, Wawancara, Watampone, 10 November 2017 
kebiasaan yang dilakukan ketika ada syukuran atau acara yang hendak dilakukan. Biasanya dengan memanggil pabbaca (pembaca doa) biasa oleh orang tua atau orang pintar yang dianggap mampu dan sudah biasa untuk memimpinkan doa, dan sebelumnya sudah ada makanan-makanan khusus yang disiapkan untuk dibacakan yang diletakkan di atas bakiatau loyang yang terbuat dari besi, ada pula dupa dengan bara api yang diletakkan dalam wadah-wadah kecil, disiapkan sebegai pelengkap yang tidak boleh ketinggalan. Ketika semuanya sudah siap, maka pabbaca langsung membacakan doa bersama makanan dengan hajat yang dimaksudkan oleh sipemilik hajat. ${ }^{29}$

Menurut hemat peneliti inti dari makna tradisi mabbaca-baca, sesungguhnya adalah sebagai tanda kesyukuran, dan sebagai sebuah wadah untuk mendoakan orang yang telah meninggal. Namun sekarang ini banyaknya pemahaman masyarakat yang menganggap hal tersebut sebagai cara kesyukuran yang ditujukan kepada sesuatu yang gaib, berupa roh-roh, dan makanan yang dibacakan diyakini akan sampai kepada pangandroangbola (penjaga rumah), atau roh orang yang telah meninggal. Dalam tradisi mabbaca-baca, juga memberikan sumbangsi pemahaman pada ziarah ke kuburan Petta Betta'E,

Banyak perilaku-perilaku yang dilakukan dalam berziarah untuk mendapatkan keberkahan dari kuburan tersebut. Seperti halnya yang dikatakan oleh $\mathrm{Hj}$. Rosi, bahwa banayak sekali orang yang datang berziarah dari Kalimantan, Jakarta yang merupakan orang-orang perantauan, mereka datang dari jauh berziarah di kuburan Petta Betta'E untuk mencari keselamatan. ${ }^{30}$ Lebih jauh lagi Faisal katakan, mereka yang datang berziarah itu tidak pulang dengan tangan kosong, namun kadang mereka mengambil batu yang ada pada kuburan tersebut dan bahkan kain pada kuburan di potong sedikit untuk dijadikan ajimat sebagai harapan usaha yang dijalankan bisa mendapatkan hasil yang baik. ${ }^{31}$

Dalam melihat proses ziarah yang ada pada kuburan Petta Betta'E, Maka ada beberapa hal yang menurut penulis perlu dianalisa dalam pandangan Islam.

a. Mengirimkan doa pada kuburan Petta Betta'E

Dalam ber Islam, doa merupakan suatu hal yang wajib untuk dilakukan sebagai pertanda seorang hamba yang lemah yang membutuhkan pertolongan kepada suatu yang lebih tinggi, dalam hal ini adalah Allah swt. dalam QS. Al-Baqarah/1:186

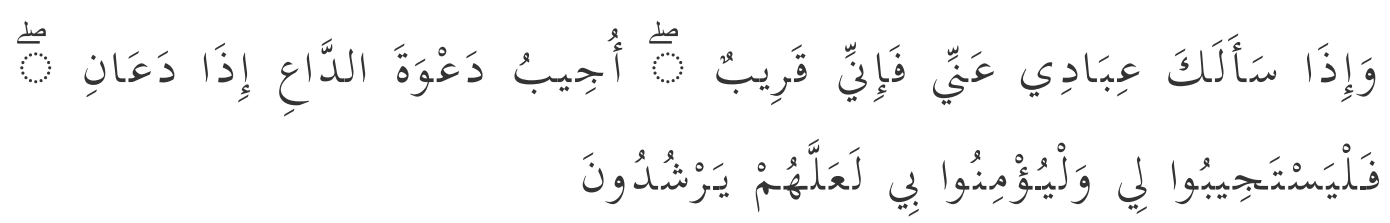

${ }^{29}$ Bunga (70 tahun), Masyarakat Palakka, Wawancara, Watampone, 10 November 2017

${ }^{30} \mathrm{Hj}$. Rosi (90 Tahun), Tokoh Adat Masyarakat Palakka, Wawancara, Watampone, 28September

${ }^{31}$ Faisal (41 Tahun), Petugas Makam Petta Betta'E, Wawancara, Watampone, 27 November 
Terjemahnya:

Dan apabila hamba-hamba-Ku bertanya kepadamu (Muhammad) tentang aku, maka sesungguhnya aku dekat. Aku mengabulkan permohonan orang yang berdoa apabila ia memohon kepada-Ku, maka hendaklah mereka itu memenuhi (segala perintah)-Ku dan hendaklah mereka beriman kepada-Ku, agar mereka selalu berada dalam kebenaran. ${ }^{32}$

Sebagai makhluk Allah hendaklah senantiasa menyertakan doa dalam setiap usaha yang dilakukan. ${ }^{33}$ Namun usaha berserta doa yang diajarkan dalam Islam berupa sesuatu yang hanya diperuntuhkan kepada Allah swt. bukan justru kepada suatu kekuatan yang lain. Dalam memandang proses ziarah pada kuburan Petta Betta'E, seperti adanya doa yang dipanjatkan kepada Petta Betta'E telah mengarah kepada harapan untuk mendapatkan keinginan duniawi yang disandarkan pada roh yang ada pada kuburan tersebut. sehingga hal itu sangatlah bertentangan dengan aqidah Islam.

Seperti halnya yang diketahui bahwa kuburan Petta Betta'E merupakan kuburan yang keberadaannya jauh sebelum masuknya Islam di Bone dan menjadi suatu kepercayaan masyarakat, sehingga ketika melihat dalam ayat al-Qur'an yang menerangkan bahwa, sebuah kekeliruan ketika kita mendoakan keselamatan dan mengirimkan bacaan-bacaan al-Qur'an, tahlil pada seorang ahli kubur yang meninggal dalam keadaan kafir, maka hal tersebut merupakan sebuah kekeliruan. Sebagaimana dalam QS. At-Taubah/9:113

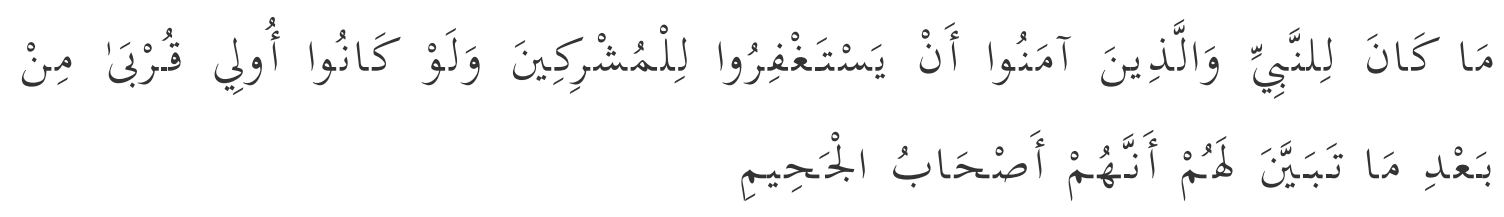

Terjemahnya:

Tiadalah sepatutnya bagi nabi dan orang-orang yang beriman memintakan ampun (kepada Allah) bagi orang-orang musyrik, walaupun orang-orang musyrik itu adalah kaum kerabat (nya), sesudah jelas bagi mereka, bahwasanya orang-orang musyrik itu adalah penghuni neraka jahanam. ${ }^{34}$

Dari penjelasan ayat diatas merupakan penegasan tentang larangan seorang mukmin mengirimkan doa kepada orang yang telah meninggal dalam keadaan kafir, namun jika dilihat dari sejarah yang mengatakan bahwa sebelum Islam masuk dan bersentuhan dengan masyarakat Bone, kuburan Petta'Betta'E telah ada, sehingga ketika kita melihat dari kacamata Islam, sosok Petta Betta'E semasa hidupnya belum

\footnotetext{
${ }^{32}$ Kementrian Agama R.I, Al-Qur'an dan Terjemahnya (Surabaya: Halim, 2014), h. 28

${ }^{33}$ Rafi'udin, Himpunan Doa-doa Muslim (Jakarta: Eska Media, 2011), h. 1

${ }^{34}$ Kementrian Agama R.I, Al-Qur'an dan Terjemahnya (Surabaya: Halim, 2014), h. 205
} 
menerima dakwah dan mengenal Islam, sehingga dapat dikatakan sebagai seseorang yang hidup di masa yang mana tidak ada ajaran Rasul yang sampai kepadanya (ahlul fatrah). Sebagaimana dalam Qs. Al-Isra/ 17: 15

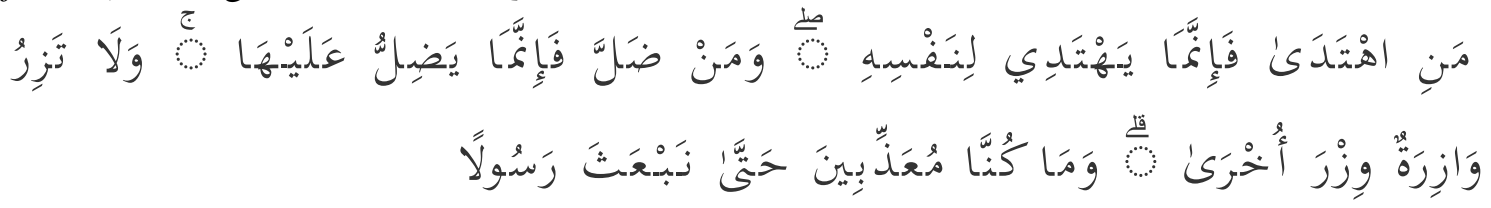

Terjemahnya:

Kami tidak akan meng'azab sebelum kami mengutus seorang Rasul. ${ }^{35}$

Ayat diatas memberikan penegas tidaklah seseorang terkena suatu hukuman ketika belum hadir kepadanya seorang Rasul, sehingga hal tersebut berlaku pada Petta Betta'E, maka untuk meziarahi dan medoakannya merupakan suatu kebolehan.

b. Menjadikan batu dan kain pada kuburan sebagai jimat

Seperti yang dikatakan yusri bahwa peziarah kadang mengambil batu dan kain yang ada pada kuburan dan dijadikan jimat bagi mereka untuk menjalankan usaha yang dijalaninya. ${ }^{36}$ Adanya perilaku peziarah dalam meyakini batu dan kain yang ada pada kuburan, menurut hemat penulis telah menjadi suatu hal yang bertentangan dalam aqidah Islam, karena adanya perilaku kesyirikan yang percaya pada suatu benda yang dapat mendatangkan sebuah kemanfaatan, padahal yang dapat mendatangkan manfaat dan mudharat hanyalah Allah swt. sebagaimana firmannya dalam Qs. Yunus/10:106

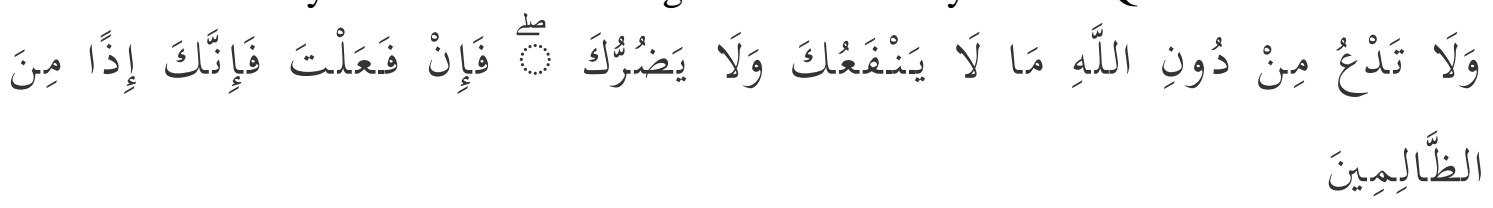

Terjemahnya:

Dan janganlah kamu menyembah apa-apa yang tidak memberi manfaat dan tidak (pula) memberi mudharat kepadamu selain Allah; sebab jika engkau melakukan (yang demikian), maka sesungguhnya engkau termasuk orang-orang yang zalim". ${ }^{37}$

Dari proses dan perilaku ziarah yang ada pada kuburan Petta Betta'E, seperti yang dijelaskan diatas, menurut hemat penulis memiliki relasi yang sangat besar dengan aqidah Islam. Karena tradisi ziarah pada kuburan Petta Betta'E merupakan suatu wadah dalam mengaplikasikan kepercayaan masyarakat, banyaknya pemahaman dan perilaku ziarah yang dilakukan telah menjadi sesuatu yang tidak sesuai dengan aqidah Islam sehingga hal tersebut telah mengotori makna ziarah kuburan yang sesungguhnya.

\section{Motivasi Ziarah Kuburan Petta Betta'E}

Motivasi (dorongan diri) merupakan kekuatan yang mampu memunculkan aktifitas dalam diri manusia. Hal ini diawali dengan adanya perilaku yang diarahkan

${ }^{35}$ Kementrian Agama R.I, Al-Qur'an dan Terjemahnya (Surabaya: Halim, 2014), h. 426

${ }^{36}$ Yusri (43 Tahun), Tokoh Agama, Wawancara, Watampone, 04 Februari 2018

${ }^{37}$ Kementrian Agama R.I, Al-Qur'an dan Terjemahnya (Surabaya: Halim, 2014), h. 220 
oleh tujuan tertentu yang menjadi aktivitas tersebut sebagai suatu tugas yang harus dilaksanakan. Motivasi inilah yang mampu mendorong manusia dalam memenuhi segala kebutuhan hidupnya, sebagaimana ia pula yang mendorong manusia dalam menjalankan banyak kegiatan penting yang bermanfaat yang sesuai dengan keinginannya. $^{38}$

Dari hasil wawancara peneliti dengan berbagai informan, apakah informan yang penulis temui langsung pada saat masyarakat melakukan ziarah, ataupun masyarakat Palakka yang selalu menyempatkan dirinya pada saat tertentu untuk berziarah dikarnakan disaat peneliti turun langsung ke lapangan hanya ada beberapa keluarga yang sedang melakukan ziarah. Seperti yang dikatakan Ibu hania, salah satu masyarakat yang berjualan disekitar kuburan bahwa ada saja peziarah yang datang tiap harinya untuk berziarah, namun yang paling banyak datang disaat hari-hari besar Islam seperti hari raya Idhul Fitri maupun Idhul adha. ${ }^{39}$

Motivasi masyarakat dalam melakukan ziarah tentunya memiliki padangan kemanfaatan, sebagaimana yang diungkapkan oleh bapak Pandu, menurutnya ziarah ke kuburan Petta Betta'E dilatar belakangi oleh tujuan-tujuan tertentu, sehingga banyak sekali dan berfariasi niatnya, akan tetapi pada intinya kebanyakan mereka datang untuk mengharapkan asalamakeng (keselamatan). ${ }^{40}$ Senada dengan pendapat Norma bahwa:

Pada engkaki ziarahi tampunna Petta Betta'E pa' anubiasani dipigau, puraki mappabbotting, jadi lokkasiki mello-ello doang, tanapodo moa magello maneng na mabbarakka maneng kehidupan rumahtanggana. ${ }^{41}$ Artinya:

Kami datang menziarahi kuburan Petta Betta'E, karna sudah biasa kita lakukan, kita baru saja telah melakukan acara pernikahan, jadi kita datang kesini untuk meminta doa, dan mudah-mudahan semua baik-baik dan kehidupan rumah tangganya selalu mendapatkan keberkahan.

Menurut yusri, bahwa yang datang untuk melakukan ziarah, sebagaian besar itu datang bertujuan untuk meminta pertolongan, atau ada niat bahkan nazar, seumpama kalau anaku dapat jodoh maka saya akan ziarah ke situ. ${ }^{42}$

Melihat tradisi ziarah pada kuburan Petta Betta'E sudah menjadi suatu hal yang terintisasi pada perilaku pengkultusan bahwa dengan melakukan ziarah pada kuburan Petta Betta'E mampu memberikan keselamatan dan pertolongan untuk peziarah.

\footnotetext{
${ }^{38}$ Nico Syukur Dister, Pengalaman dan Motivasi, Beragama: Pengantar Psikologi Agama (Jakarta: Leppanas, 1982), h. 6

${ }^{39}$ Hania (52 Tahun), Masyarakat Palakka, Wawancara, Watampone, 27November 2017

${ }^{40}$ Pandu (45 Tahun), Masyarakat Palakka, Wawancara, Watampone, 05 Februari 2018

${ }^{41}$ Norma (40 Tahun), Peziarah, Wawancara, Watampone, 27 November 2017

${ }^{42}$ Yusri (43 Tahun), Tokoh Agama, Wawancara, Watampone, 04 Februari 2018
} 
Petta Betta'E bukanlah sosok yang dianggap sebagai orang shaleh yang memiliki pengaruh besar dalam sejarah pengembangan Islam pada masyarakat Bone. Namun Petta Betta'E hanyalah merupakan sosok leluhur yang difahami keberadaannya jauh sebelum Islam. Berbeda halnya berziarah ke kuburan-kuburan keramat pada umumnya yang semasa hidupnya merupakan tokoh penyebar ajaran Islam, yang selalu dikisahkan dengan sosok keshalehan dan kewaliannya, sehingga kedekatannya kepada Allah swt. mampu menjadi washilah (perantara) bagi para peziarah dalam menyampaikan hajat-hajatnya.

Diluar dari perbedaan pandangan para ulama tentang kebolehan bertawassul/berwasilah kepada orang yang shaleh, dan yang terlihat bahwa Petta Betta'E bukanlah sosok yang dianggap sebagai seorang yang shaleh dan hanya sebatas leluhur yang dihormati dan ditakutioleh masyarakat. Dan bahhkan sosok Petta Betta'E juga bukan sebagai wasilah untuk mendekatkan diri kepada Allah, dan justeru pertolongan dari ahli kubur maka hal itu telah mengotori aqidah masyarakat. Padahal dalam al-Qur'an yang dapat memberikan keselamatan hanyalah Allah swt. Seperti dalam Qs. Az-Zumar/39:38

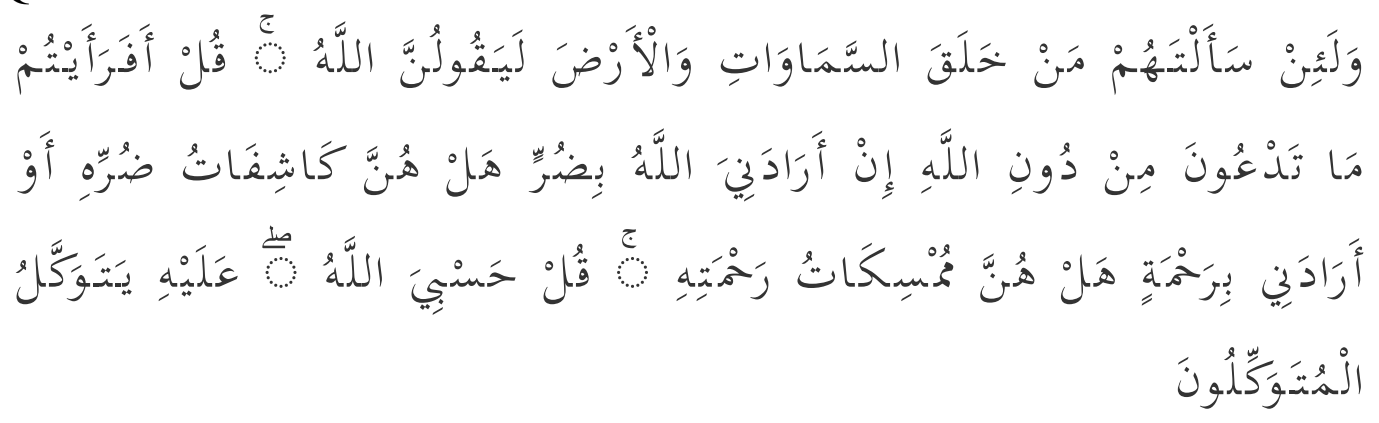

Terjemahnya:

Dan sungguh jika kamu bertanya kepada mereka: "Siapakah yang menciptakan langit dan bumi?", niscaya mereka menjawab:"Allah". Katakanlah: "Maka Terangkanlah kepadaku tentang apa yang kamu seru selain Allah, jika Allah hendak mendatangkan kemudharatan kepadaku, apakah berhala-berhalamu itu dapat menghilangkan kemudharatan itu, atau jika Allah hendak memberi rahmat kepadaku, apakah mereka dapat menahan rahmat-Nya?. Katakanlah: "Cukuplah Allah bagiku". kepada- Nyalah bertawakkal orang-orang yang berserah diri. ${ }^{43}$

Ayat di atas memberikan penjelasan tentang menghindari adanya kecenderungan mengharapkan sesuatu selain kepada Allah dalam meraih kebaikan atau menolak suatu keburukan, maka itu merupakan perbuatan yang tidak diridhoi oleh Allah swt.

${ }^{43}$ Kementrian Agama RI, Al-Qur'an dan Terjemahnya (Surabaya: Halim, 2014), h. 462 


\section{V.PENUTUP}

Berdasarkan uraian di atas, maka fenome tradisi ziarah pada kuburan Petta Betta'E pada masyarakat Kabupaten Bone memiliki relasi dengan aqidah Islam, karena dalam tradisi ziarah yang dilakukan memiliki proses dan motivasi yang perlu adanya pemahaman dan bahkan telah menjadi suatu yang bertentangan dalam aqidah Islam, seperti mengirimkan doa, mengambil batu dan kain pada kuburan sebagai jimat, bahkan motivasi dalam menziarahi kuburan sebagai tempat untuk meminta pertolongan. 


\section{DAFTAR PUSTAKA}

Abdullah, Hamid Al-Humaidi, Bid'ah-Bid'ah Kubur, terj. Abdul Rosyad Shiddiq Jakarta: Pustaka Al-Kautsar, 2003.

Agama, Kementrian RI, Al-Qur'an dan Terjemahnya Surabaya: Halim, 2014.

Asnawi, Sibtu, Tata Cara Ziarah Kubur, Kudus: Menara, 1983.

Boghdan, Robert dan Steven J. Taylor, Pengantar Metodologi Penelitian Kualitatif, terj. ArifFurchan Surabaya: Usaha Nasional, 1992.

Buhairi, Syaikh Mamduh Farhan al-, Kuburan Agung, Menyingkap Fenomena Ketergantungan Kepada Para Wali, terj. A. Hasan Bashori Jakarta: Darul Haq, 2005.

Dister, Nico Syukur, Pengalaman dan Motivasi, Beragama: Pengantar Psikologi Agama Jakarta: Leppanas, 1982.

Eliade, Mircea et. Al, The Encyclopedia of Religion New York: Macmillian Publishing Company, 1987.

Esposito, John L., Ensiklopedi Oxford Dunia Islam Modern Bandung: Mizan, 2001.

Koentjaraningrat, Antropologi Budaya, Jakarta: PT. Rineka Cipta, 2009.

Koentjaraningrat, Pengantar Ilmu Antropologi Jakarta: Aksara Baru, 1980

Mahmudi, Motivasi Ziarah Makam Bagi Masyarakat Islam Studi Kasus Para Peziarah Makam Batu Ampar, Tesis Surabaya: Pasca Sarjana Iain Sunan Ampel, 2004.

Mashudi, Ziarah Kemakam Islam Sunan Ampel Surabaya Surabaya: Jurnal Sastra dan Sejarah, No. 2/II/1999.

Rafi'udin, Himpunan Doa-doa Muslim Jakarta: Eska Media, 2011

Stannard, Russel, Tuhan Abad 21, terj. Happy Susanto Yogyakarta: Belukar Budaya, 2004.

Sztompka, Piotr, Sosiologi Perubahan Sosial Jakarta: Prenada media Group, 2012.

Sumber Wawancara

A. Rizki Arwansyah (32 tahun), Sejarawan Bone, Wawancara, Watampone, 20 November 2017

H. Rijal (37 tahun), Masyarakat Palakka, Wawancara, Watampone, 20 Mei 2018

Apping (34 tahun), Sejarawan Bone, Wawancara, Watampone, 20 November 2017

Bunga (70 tahun), Masyarakat Palakka, Wawancara, Watampone, 10 November 2017

Dg. Rakile (75 tahun), Juru Kunci Makam, Wawancara, Watampone, 27 November 2017

Hj. Rosi (90 Tahun), Tokoh Adat Masyarakat Palakka, Wawancara, Watampone, 28September 2017

Faisal (41 Tahun), Petugas Makam Petta Betta'E, Wawancara, Watampone, 27 November 2017

Yusri (43 Tahun), Tokoh Agama, Wawancara, Watampone, 04 Februari 2018

Hania (52 Tahun), Masyarakat Palakka, Wawancara, Watampone, 27November 2017

Pandu (45 Tahun), Masyarakat Palakka, Wawancara, Watampone, 05 Februari 2018

Norma (40 Tahun), Peziarah, Wawancara, Watampone, 27 November 2017 